\title{
- Splitting Hairs: Female Fetishism and Postpartum Sentimentality in Maupassant's Fiction
}

- Maupassant's short story "Une Veuve" opens during hunting season at the château de Banneville. ${ }^{1}$ Outside all is wet and dreary, and the guests, gathered inside the salon, tell stories in an effort to stave off boredom. The stories fail to amuse or distract- "the women wracked their brains but never managed to discover the imagination of Scheherazade." But suddenly a young woman notices a curious ring of hair on the hand of a maiden aunt: "Tell me, Aunt, what is that ring? One would think it the hair of a child," she remarks. "It's sad, so sad that I never want to speak of it. It is the cause of all the sadness of my life," the aunts replies. ${ }^{2}$ Their curiosity finally roused, the guests implore her to divulge the mystery, and after much postponed gratification, she relents and tells her tale.

This classic prelude, a typical Maupassant frame-text, immediately sets the tone for a lachrymose drama of mourning, melancholia, and manic collecting. The lugubrious nineteenth-century practice of preserving the relics of departed loved ones, from keepsakes and love letters to nail clippings and locks of hair, is here pastiched through postiche, literally through a piece of hair, figuratively through the atmosphere of artifice, simulation, and ersatz reproducibility,

1. I am grateful to Lynn Hunt for inviting me to present an initial version of this chapter in a conference, "Eroticism and the Body Politic," at the University of Pennsylvania, Apr. 1988. Naomi Schor and Carla Hesse offered particularly useful and provocative criticism in the course of our discussion.

2. Guy de Maupassant, Contes et nouvelles, 2 vols., ed. Louis Forestier (Paris: Gallimard, 1974-79), 1:533. 
which impregnates Maupassant's ironic evocations of late romantic nostalgia. ${ }^{3}$ Close in ethos to the bric-a-brac-cluttered world of Baudelaire's spleen poems, Maupassant's "Une Veuve" invites classification as gynotextual fetishism, that is, a female fetishism traversing literary and psychoanalytical boundaries and defined from a woman's point of view. ${ }^{4}$ Maupassant's descriptions of feminine neurosis, modeled on his own actual observations of Charcot's choreographed exhibitions of female hysteria at the Salpêtrière hospital, frequently highlight the frenetic, erotic mourning rituals of women. ${ }^{5}$ Despite a male narrative perspective, the case-history value of his texts on the feminine-some narrated in the firstperson feminine voice, others projecting a feminine Imaginary through third-person omniscient narration-becomes increasingly apparent when read in conjunction with feminist theory. Legible in the fanatical attachments of his female protagonists to the secret contents of their secrétaires and tiroirs (as in, for example, his stories "La Relique" ["The Relic"], "Souvenirs" ["Memories"], and "Vieux objets" ["Old Things"]), discernible in the maternal reliquary fashioned to enshrine childhood relics (Une Vie [A Woman's Life]), and manifest in the erotically charged "fantasms of the exquisite cadaver" through which his male characters conflate women and sepulchral desire ("Les Tombales" ["Graveyard Sirens"], "L Apparition" ["An Apparition"], "La Morte" ["Death"]), the outline of a sentimental sickness emerges akin to the great feminine pathologies of the nineteenth century: hysteria, hypochondria, somnambulism, and frigidity. ${ }^{6}$

3. The word postiche (from the Italian posticcio, or part) is defined by Littré's dictionary as "une sorte d'ornement," and generally refers to "false hair," or hair piece. The figurative connotations of the word ("se dit de ce qui est factice, simulé, qui cache quelque chose sous des apparences trompeuses" [cf. Larousse]) suggest a strong affinity to the term fetishism, which derives from the Latin facticius, meaning "artificial." For French histories of hair fashions off ering illuminating descriptions of the fin-de-siècle fascination with artificial tresses (often called anglaises), see A. Chantoiseau, Le Coiffeur et la Chevelure (Paris: Ed. Ulysse Boucoiran, 1938), and René Rambaud, Les Fugitives: Précis anecdotique et histoire de la coiffure féminine à travers les âges (Paris: S.E.M.P., 1955). See also Pamela A. Miller, "Hair Jewelry as Fetish," in Ray B. Brown, ed., Objects of Special Devotion: Fetishes and Fetishism in Popular Culture (Bowling Green, Ohio: Bowling Green University, 1982).

4. For an essay treating fetishism in general (as opposed to female fetishism) in Maupassant's oeuvre, see Philippe Lejeune, "Maupassant et le fétichisme," in Maupassant, miroir de la nouvelle, ed. Jacques Lecarme and Bruno Vercier (Paris: Presses Universitaires de Vincennes, 1988), pp. 91-109. This chapter is indebted to my discussions of fetishism in Maupassant with Philippe Lejeune.

5. For a discussion of Maupassant's psychoanalytical education, see Elisabeth Roudinesco, La Bataille de cent ans: Histoire de la psychanalyse en France, vol. 1: 1885-1939 (Paris: Seuil, 1986), pp. 79-81.

6. Maria Torok, "Maladie du deuil et fantasme du cadavre exquis," Revue 
Though eighteenth-century philosophy had recognized lâme sensible (the sensitive soul) as the mark of a healthy sentimentalism essential to the elevated moral character of the enlightened individual, nineteenth-century psychology saw such excessive outpourings of tenderness as bordering on the perverse. ${ }^{7}$ Maupassant's representation of this ailment, which he characterized in Une Vie as "une sorte d'instinct héréditaire de sentimentalité rêveuse [a kind of hereditary instinct of dreamy sentimentality]" not only provides the foundation for correcting the gender-biased definitions of fetishism developed by Freud and his medical precusors but also offers an invaluable portrait of sentimental obsession in the nineteenth century. ${ }^{8}$

The fin-de-siècle representation of feminine collecting belongs to a broader European genre, including the Biedermeier novel in Germany (best typified by Adalbert Stifter's Der Nachsommer [Indian Summer]) and British hearth-and-home fiction (filled with descriptions of what Asa Briggs has called "Victorian things," as in Dickens's Old Curiosity Shop [1841]). Stylistically realist, its narrative surface worked over with a mosaic of painstakingly observed domestic details, this literary fetishism features characterizations of women who vented their phobias and passions through reverent attachments to nostalgic souvenirs. Une Vie, already powerfully analyzed from a feminist viewpoint by Naomi Schor, provides a clear example of the genre. ${ }^{9}$ Even though the female protagonist tends to confirm outmoded stereotypes of feminine behavior, many of these very stereotypes, in addition to having historical value as images

Française de Psychanalyse 4 (1968): 715-33.

7. In her discussion of "healthy sentimentality" in the eighteenth century, Jan Goldstein, in her Console and Classify: The French Psychiatric Profession in the Nineteenth Century (Cambridge: Cambridge University Press, 1987), has defined its place within Enlightenment codes of sensibility: "Thus certain stereotypic marks-tenderness for little children, the blissful harmony ascribed to the family circle, tears flowing freely and copiously in response to familial joys or sorrows - connect the moral treatment and its proponents' concept of human nature to the eighteenth-century cult of sentimentality.... Pinel's Rousseauism takes on an added dimension when seen from this vantage point. The author whose Nouvelle Héloise had called forth floods of "delicious" tears from his grateful readers would have special significance for the physician who regarded an appropriately tearful sentimentality as a definitive sign of mental health" (p. 118).

8. Guy de Maupassant, Une Vie (Paris: Garnier-Flammarion, 1974), p. 150; trans. H.N.P. Sloman, under the title $A$ Woman's Life (Harmondsworth: Penguin, 1982). In characterizing the baroness's affliction of hypersentimentality, Maupassant also uses the more medicalized expression "une hypertrophie du coeur." Further references to the French edition will be abbreviated $U V$; to the English, $W L$.

9. Naomi Schor, Breaking the Chain: Women, Theory, and French Realist Fiction (New York: Columbia University Press, 1985). 
drawn on by early psychiatry, have been, if not rehabilitated, then at least reevaluated by contemporary feminist psychoanalysis in its search for alternatives to masculine norms of sexuality.

Within the nineteenth-century epistemology of perversion there was, as we have seen, a fairly clear demarcation between feminine pathology and male perversion. With the exception of female homosexuality, practices such as fetishism, sadomasochism, exhibitionism, and voyeurism required a male agent in the early chronicles of deviant practice. After stating explicitly that the "hair of man, especially the beard, the emblem of virility, the secondary symbol of generative power-is a predominant fetish with woman," Krafft-Ebing foreclosed all clinical seriousness as far as female perversion was concerned by adding, "The author has thus far not succeeded in obtaining facts with regard to pathological fetishism in women." 10 As defined by the early psychoanalysts, fetishism was the decadent creation of a male erotic imagination spurred by castration anxiety or repressed homosexuality. And despite his admission at the Vienna Psychoanalytic Society in 1909 that "all women... are clothing fetishists," Freud tended to reinforce this male homosexual typecasting with his theory of the coprophilic drive. ${ }^{11}$ Typical fetish objects such as feet and hair (associated with dirt or animal odors) were seen as evidence that the subject was arrested at the anal stage of development. ${ }^{12}$ Regressive (in returning to that last infantile moment at which the illusion of a phallic mother reigned supreme) and predisposed to anal eroticism (hence his homosexual leanings), the fetishist and homosexual alike failed, according to Freud, to acquire that immunizing disgust so necessary to socialization.

Feminist critics have been hard-pressed to furnish case histories of female fetishism. Naomi Schor, discussing typologies of male

10. Richard von Krafft-Ebing, Psychopathia Sexualis, trans. Dr. Harry E. Wedeck (New York: Putnam, 1965), p. 41.

11. Freud, "Fetishism" (1927), Standard Edition 21:152-57. See also the important essay "Splitting of the Ego in the Process of Defence" (1938), in which Freud describes a typical instance of phallic displacement as it is performed by a male subject on the female body: "This displacement, it is true, related only to the female body; as regards his own penis nothing was changed" (Freud, Standard Edition, 23:278).

1 2. "Psychoanalysis ... has shown the importance, as regards the choice of a fetish, of a coprophilic pleasure in smelling which has disappeared owing to repression. Both the feet and the hair are objects with a strong smell which have been exalted into fetishes after the olfactory sensation has become unpleasurable and been abandoned" (Sigmund Freud, Three Essays on the Theory of Sexuality, Standard Edition $7: 155)$. 
fetishism in the work of George Sand, acknowledges that "female fetishism, is, in the rhetoric of psychoanalysis, an oxymoron."13 Among the first to address the issue, Schor is fully aware of the contradictions that arise when Freudian or Lacanian terms are applied and criticized at the same time. Her own textual interpretations consistently pose the problem of how one stands both inside and outside the Freudian lexicon, invoking its normative frameworks while questioning its oedipally centered premises. Schor does succeed, however, in compiling a bibliography of case histories: G. A. Dudley, she notes, "dephallusized the fetish," arguing that the "fetish may... be a substitute for other infantile objects besides the penis." George Zavitzianos claimed that for his female fetishist (who seems to have adopted a male sexual identity and adapted the Electra complex) the fetish corresponded to the paternal phallus. Gérard Bonnet, using Lacan's distinction between "having and being" the phallus, refers to the case of a female fetishist who, in Schor's words, "responds to her mother's desire by wanting to be her (missing, absent) phallus." 14 Schor also mentions Piera AulagnierSpairani, a feminist Lacanian, who imputes a kind of female fetishism to conditions of acute jealousy in which women suspect not just female rivals, but all objects (animate or inanimate) capable

13. Naomi Schor, "Female Fetishism: The Case of George Sand," in The Female Body in Western Culture, ed. Susan Sulieman (Cambridge: Harvard University Press, 1986), p. 263. In her introduction to this piece, Schor specifies that her concern "is not to counter phallocentrism by gynocentrism, rather to speculate on modes of reading that might be derived from the female body, a sexual body whose polycenteredness has been repeatedly emphasized by feminist theoreticians." I have followed Naomi Schor in the exploration of fetishism as a "polycentered" (and polymorphous) perversion, but where Schor keeps the main outlines of a malecentered Freudian fetishism intact (dislocating Freud's definition by examining its workings in the writing of a woman author and a female character), I have pursued the opposite course: revising the Freudian definition away from phallocentrism with the help of literary descriptions of female fetishism provided by a male author.

14. Like Freud, Lacan argued that fetishism was not a problem for women: "Since it has been effectively demonstrated that the imaginary motive for most male perversions is the desire to preserve the phallus which involved the subject in the mother, then the absence in women of fetishism, which represents the virtually manifest case of this desire, leads us to suspect that this desire has a different fate in the perversions which she presents." Though Lacan does acknowledge sexual difference in relation to the problem of fetishism ("For to assume that the woman herself takes on the role of fetish, only raises the question of the difference of her position in relation to desire and to the object"), he still reverts to the image of a phallus-envying female homosexual ("giving what she does not have") as a counterpart to the male fetishist (Jacques Lacan, "Guiding Remarks for a Congress on Feminine Sexuality," in Feminine Sexuality, ed. Juliet Mitchell and Jacqueline Rose, trans. Jacqueline Rose [New York: Norton, 1985], p. 96). 
of attracting male attention. ${ }^{15}$ Here, female fetishism, synonymous with the reification of women by women, reveals itself to be an extension of some profound, masochistic will to self-objectification (evident, at a superficial level, in a woman's desire to make herself into a sex object). One may infer that for Aulagnier-Spairani, women are ontologically fetishistic because of the ease with which they operate in the realm of the simulacrum: parure, doll-like affectations, narcissistic displays of isolated parts of the body, and the faked orgasm are just so many modalities of this essentially artificial sexuality. ${ }^{16}$ Schor concludes that no matter how one tries to define female fetishism, it remains, if it exists at all, an "appropriation" ("a sort of 'perversion-theft") of a dominantly male disorder and thus disconcertingly close to "the latest and most subtle form of 'penis-envy'."17

To my knowledge, the only other truly novel attempt to theorize female fetishism otherwise has been Elizabeth Grosz's conjugation of lesbian fetishism. Grosz compares the male fetishist to the woman with a "masculinity complex" by means of their common disavowal of castration:

Freud suggests that although the masculinity complex may not necessarily imply lesbianism, nevertheless many lesbians can be classified under this label. Where the so-called "normal" path to femininity involves accepting her castration and transferring her libidinal cathexes from the mother to the father (via penis envy), with the accompanying transformation of her leading sexual organ from the clitoris to the vagina (with its associated position of passivity), the woman suffering from the masculinity complex retains the clitoris as her leading sexual organ and the position of activity it implies. ${ }^{18}$

As Grosz makes clear, the lesbian fetishist hermeneutically empowers the clitoris as a means of not giving up the phallus. ${ }^{19}$ If the

15. Ibid., p. $36_{5}$.

16. Piera Aulagnier-Spairani, "Remarques sur la féminité et ses avatars," in Le Désir et la perversion (Paris: Seuil, 1967), pp. 53-9o. This volume also contains other excellent pieces on fetishism, most notably Guy Rosolato's "Etude des perversions sexuelles à partir du fétichisme."

17. Schor, "Female Fetishism," p. 371.

18. Elizabeth Grosz, "Lesbian Fetishism," in Fetishism as Cultural Discourse: Gender, Commodity, and Vision, ed. Emily Apter and William Pietz (Ithaca: Cornell University Press, forthcoming). Further references to this essay will be abbreviated G.

19. Naomi Schor also makes the case for "clitoral hermeneutics" broadly defined as a mode of interpretation focusing on the detail and grounded in the textual extrapolation of the female body. See her "Female Paranoia: The Case for Psychoanalytic Feminist Criticism," Yale French Studies, no. 62 (1981): 204-19. 
phallus is to be relinquished (and of course, as Lacan reminds us, it is retained by neither sex), the lesbian fetishist, like the male fetishist, will continue to love the phallus "elsewhere": "She takes on a substitute for the phallus, an object outside her own body" (G 14). This substitute phallus, Grosz provocatively suggests, can take the form of another woman-"a 'phallic' woman, a woman precisely, one may suspect, with a masculinity complex." Preserving her ideal of a preoedipal phallic mother, the lesbian subject makes a fetish of woman, and in the process, depreciates Freud's penis-envy hypothesis by changing the referential status of the phallus from penis to clitoris.

Though female narcissism and lesbian fetishism have their place in my reading of Maupassant's fiction, the interpretive emphasis falls on what the contemporary artist Mary Kelly has gently satirized as the modern housewife's preoedipal, precapitalist object cathexis. This love, involving what Kelly calls an "archaizing of the drives," veers toward domestic artifacts stamped with the coprophilic odors of the real: flowers, clothing, keepsakes, baby relics. The close resemblance between this figure of the female fetishist and Freud's historic coprophilic homosexual fetishist seems hardly coincidental. Clearly there was a place for this female "pervert," who, alongside her male counterpart, suffered from castration anxiety and yearned to regress to the anal erotic stage. Clearly there were female fetishists whose manic collectomania was never recognized as perverse because it was naturalized as a typical feminine pastime.

Why, one might ask (along with Schor and Grosz), would one want to revise the historical record so as to allow women to be fetishists? Part of the answer is that the male gendering of this perversion always seems to entail some complementary theory of female "genital deficiency." in 1923 as a form of homosexuality, maintained that "fetishism always develops into a depreciation of the female, regardless of the causes, and the same is true of the few cases of female fetishism

20. See Freud's argument in "Femininity," in Standard Edition 22:132 and 134, where he argues: "The effect of penis-envy has a share, furthermore, in the physical vanity of women, since they are bound to value their charms more highly as a late compensation for their original sexual inferiority," and "Shame, which is considered to be a feminine characteristic par excellence but is far more a matter of convention than might be supposed, has as its purpose, we believe, concealment of genital deficiency." See also Luce Irigaray's important critique of these passages in chap. 1 of Speculum of the Other Woman, trans. Gillian C. Gill (Ithaca: Cornell University Press, 1985), pp. 112-13. 
which I have been able to observe." ${ }^{21}$ Another response to this genuinely irksome question centers on the conviction that a current rereading of historical femininity dislocates essentialism through the instantiation of perversion. In this case, then, a woman's search for jouissance in the socially sanctioned rituals of object veneration would be seen no longer as a manifestation of a tame, essential femininity but, rather, as the semiosis of a subversively erotic practice, thoroughly "perverse" in its own terms.

The first theorist of female fetishism in the history of psychiatry was Gaëtan Gatian de Clérambault. ${ }^{22}$ A descendent of Descartes and Alfred de Vigny, an iconoclastic contemporary of Freud, and a teacher of Jacques Lacan, Clérambault left a body of work on the obsessive gaze that was the foundation, many have surmised, for Lacan's theory of the mirror stage. His own suicide provides a macabre gloss: when he shot himself in front of a mirror, the bullet exited through his eye. Clérambault's clinical career demonstrated the cliche of the "doxic" doctor who suffers from the very psychosis that he specializes in curing. ${ }^{23}$ Fixated on cloth textures and draped fabric, he wrote on Greek costume and photographed Moroccan women mysteriously enshrouded in their chadors and veils. Clérambault also diagnosed this same passion des étoffes in his female patients. Jacqueline Rose's description' of scopophilic desire aptly describes the particular kind of specular blindness that characterized Clérambault's analytical pose: "The relationship of the scopic drive to the object of desire," she writes, "is not simply one of distance but of externalisation, which means that the observing subject can become object of the look, and hence elided as subject of its own representation." ${ }^{24}$

Though subject to the whimsy of his own ocular distortions (he was also the author of Souvenirs d'un médecin opéré de la cataracte [Memoirs of a doctor operated on for cataracts]), Clérambault's

21. Wilhelm Stekel, Sexual Aberrations: The Phenomenon of Fetishism in Relation to Sex (New York: Liveright, 1930), p. 3.

22. Feminist critics have just begun to work on Clérambault. Joan Copjec provides an incisive Lacanian analysis of Clérambault's photographs in her article "The Sartorial Superego," October 5o (Fall 1989): 57-95. Jann Matlock historically situates Clérambault's work within nineteenth-century psychiatry and draws connections between his female fetishism and medical commentary on cross-dressing in her essay "Masquerading Women, Pathologized Men: Cross-dressing, Fetishism, and the Theory of Perversion, 1882-1935," in Apter and Pietz, Fetishism as Cultural Discourse.

23. Roudinesco, La Bataille 2:121-27.

24. Jacqueline Rose, Sexuality in the Field of Vision (London: Verso, 1986), p. 196. 
theoretical reflections on his feminine case histories, published as early as 1908 , offers a haptic or touch-oriented eroticism that also appears to have been the first gender-free conception of fetishism. This theoretical advance was made, however, en pleine dénégation (in full disavowal), for Clérambault refused in principle to admit women into the elite precinct of male perversion. In his "Passion érotique des étoffes chez la femme" [The erotic attraction to drapery in women] he took great pains to uphold a hairsplitting distinction between male and female sexual fantasy:

- A remarkable trait of fetishists, sadists, homosexuals, and masochists is the extreme abundance of their dreams relative to the object of their passion. Even beyond onanism, they devote themselves to veritable debaucheries of the imagination the object of which is their favorite act; they celebrate it in writing and drawing; throughout masturbation with the fetish they project splendid scenes.

... In the case of our three [female] patients, we find nothing of the kind; they masturbate with silk, with no more fantasy than a solitary epicure savoring a delicate wine. ${ }^{25}$

Clérambault's hypotheses that women alone require this type of tactile stimulation and that pieces of cloth constitute inadequate vehicles of orgasm are radically put into question when we consider his own lovingly handled photographic albums of draped females (rumored to number well over a thousand images) or his personal collection of feminine wax figurines. Moreover, his transcriptions of case histories blatantly contradict his claim that women possess less erotic imagination than men.

Where Clérambault was hampered by psychoanalytical and sexist prejudices that weakened the value of his observations, Maupassant, never one to underestimate the capacity of either sex for "veritable debaucheries of imagination," proved to be the more reliable analyst. Hair fetishism, for example, surfaces in two exemplary tales, one told from a masculine, the other from a feminine, point of view. In "La Chevelure," an antique collector, thrilled by the purchase of a seventeenth-century Italian chest, is brought to fever pitch upon discovering a tress of hair in one of the drawers: ${ }^{26}$

25. G. G. de Clérambault, La Passion des étoffes chez un neuropsychiatre, ed. Yolande Papetti et al. (Paris: Solin, 1981), pp. 34-35.

26. For an interesting reading of a medieval analogue to Maupassant's La Chevelure, see Jean-Charles Huchet's psychoanalytical interpretation of the fabliau Des Tresces in his article "De la perversion en littérature," Poétique, no. 71 (Sept. 1987): 272-8o. 
- Oui, une chevelure, une énorme natte de cheveux blonds, presque roux, qui avaient dû être coupés contre la peau, et liés par une corde d'or.

Je demeurai stupéfait, tremblant, troublé! Un parfum presque insensible, si vieux qu'il semblait l'âme d'une odeur, s'envolait de ce tiroir mystérieux et de cette surprenante relique.

Je la pris, doucement, presque religieusement, et je la tirai de sa cachette. Aussitôt elle se déroula, répandant son flot doré qui tomba jusqu'à terre, épais et légère, souple et brillant comme la queue en feu d'une comète.

- Yes, a head of hair, an enormous plait of blond hair, almost red, which must have been cut off against the skin and tied together by a gold cord.

I remained stupefied, trembling, perturbed! An almost anesthetizing perfume, so old that it seemed to be the soul of an odor, flew from this mysterious drawer as well as from this amazing relic.

I picked it up, gently, almost religiously, and I took it from its hiding place. Immediately, the tress unfurled, spilling its gilded wave which fell to the ground, thick and light, supple and brilliant, like the fiery tail of a comet. $^{27}$

Maupassant's staged description, replete with a figure of phallic displacement ("la queue en feu"), a coprophilic attraction to odor, and a brilliant shine (approximating Freud's famous "Glanz auf der Nase"), seems to parody rather than to anticipate Freud. Like the flower fetishist in "Un Cas de divorce," or the libertine haunted by a lady's birthmark in "Une Inconnue," the antique dealer joins the ranks of male characters distinguished by their aberrantly focused erotic "regard."28 But lest one believe that this textbook fetishism is restricted to male personnages, one need only read "La Moustache," in which the female narrator recounts her singular fixation on male facial hair:

- D'où vient donc la séduction de la moustache, me diras-tu? Le sais-je? D'abord elle chatouille d'une façon délicieuse. On la sent avant la bouche et elle vous fait passer dans tout le corps, jusqu'au bout des pieds, un frisson charmant. C'est elle qui caresse, qui fait frémir et tressaillir la peau, qui donne aux nerfs cette vibration exquise qui fait pousser ce petit "ah!" comme si on avait grand froid.

27. Maupassant, Contes et nouvelles 2:110.

28. An interesting interpretation of these short stories in relation to La Chevelure was made by Philippe Lejeune in his talk "Maupassant et le fétichisme," at a conference titled "Maupassant et la nouvelle" at Cerisy-la-salle, July 1986. 
Where then does the seduction of the mustache come from, you ask me? Do I know? At first, it tickles in a delicious fashion. One feels its contact before the mouth and it sends a charming shudder through the body, to the tips of the toes. It's the mustache that caresses, making the skin quiver and tremble, giving the nervous system an exquisite vibration that provokes that little "ah!" as if one had suddenly caught cold. ${ }^{29}$

As in "La Chevelure," the hirsute object of desire inserts itself in a trichophilic literary tradition including Mathilde's impassioned sacrifice of "a whole side of her beautiful head of hair" to her lover Julien Sorel in Le Rouge et le noir; Charles Bovary's lonely death with "a long strand of black hair" clasped between his hands like a book of prayer (and this despite his humiliating discovery of Emma's infidelities); Baudelaire's evocations of the intoxicating odors and serpentine movements of his mistress's heavy tresses in "La Chevelure," "Parfum exotique," Fusées, and Les Paradis artificiels; or the scene in act 3 of Maeterlinck's Pelléas et Mélisande, which begins with Mélisande's seductive call: "My hair awaits you the length of the tower," and culminates in Pelléas's fevered declaration: "All your hair, Mélisande, all your hair is falling from the tower! I am holding it in my hands, against my mouth, in my arms.... It lives like birds between my fingers, and it loves me, loves me more than you." Where each of these precedents depends on a male hair fetishist, the narrator of "La Moustache" stands out as transgressively different. Certainly an aura of transgression prevails in the passages cited above, a transgression preserved in the subversive term "bisextuality," adapted by Naomi Schor to characterize a "perverse oscillation, a refusal ... firmly to anchor woman-but also man-on either side of the axis of castration." ${ }^{30}$ In deploying this neologism, Schor implicitly endorses Sarah Kofman's Derridean notion of textual "oscillation," or undecidability. In "Ça cloche," Kof man had called for "un fétichisme généralisé," positively valorized ("bref pourquoi c'est si mal d'être fétichiste [in short, what's wrong with being a fetishist]") and no longer bound to a single gender. ${ }^{31}$

Kof man seeks to raze the negative history of the fetish, removing it from its Kantian ascription as a degraded sublime ("a trifle"), erasing its Marxist connotations as a spectral figure of alienated value (commodity fetishism), and displacing it from the feminist

29. Maupassant, Contes et nouvelles 1:919-20.

30. Schor, "Female Fetishism," p. 369 .

31. Sarah Kofman, "Ça cloche," in Les fins de l'homme: A partir du travail de Jacques Derrida (Paris: Galilée, 1981), p. 99. 
lexicon where it denotes the exploitative, anatomically decorticating male gaze found in pornography, advertising, and art. ${ }^{32}$ In her reediting of fetishism, Kof man challenges its phallocentric orientation, arguing that, regardless of sex, the fetish is generated as a guarantee against the disappearance of an idealized phallus, itself already a representation. A representation of a representation, itself representative of radical undecidability, the fetish is thus redeemed; formerly a degraded truth-value and icon of sexist psychoanalysis, it is now recast as the foundation for an ironic, gender-free metaphysics.

Kofman succeeds in demasculinizing fetishism through theory but in the process dispenses almost entirely with sexual difference. Female fetishism, insofar as it could even be epistemologically distinguished according to her terms, is subsumed within the neutered modalities of textual indeterminacy. Such an indeterminacy is exemplified in Maupassant's fiction in "Clochette", a story that puts the title of Kofman's own essay, "Ça cloche" (emphasizing the analogy between the bipolar movement of the clapper and the "bitextuality" of Derrida's Glas, Kofman's master text of "oscillation"), ironically into play. Clochette is the name of a family seamstress whose hairy face makes her an interesting specimen of "bisextuality":

- C'était une haute femme maigre, barbue, ou plutôt poilue, car elle avait de la barbe sur toute la figure, une barbe surprenante, inattendue, poussée par bouquets invraisemblables, par touffes frisées qui semblaient semées par un fou à travers ce grand visage de gendarme en jupes. Elle en avait sur le nez, sous le nez, autour du nez, sur le menton, sur les joues; et ses sourcils d'une épaisseur et d'une longueur extravagantes, tout gris, touffus, hérissés, avaient tout à fait l'air d'une paire de moustaches placées là par erreur.

- She was a tall, thin woman, bearded, or rather, hairy, since she had patches of beard all over her face-an amazing, unexpected beard, growing in unbelievable clumps, in curly clusters that seemed sowed by a madman across the visage of this gendarme in skirts. She had hair on her nose, around the nose, on her chin, on her cheeks; and her

32. For an interesting discussion of the philosophical history of fetishism and its links to the eighteenth-century study of religion in "primitive" societies, see William Pietz, "The Problem of the Fetish, I," Res 9 (Spring 1985): 5-17. For an interesting critique in art of fetishism in advertising and pornography, see catalogs of two shows held at the New Museum of Contemporary Art in New York: Difference: On Representation and Sexuality (1984) and Damaged Goods (1986). 
eyebrows, of a preposterous thickness and length, all gray, shaggy, and spiky, had the air of a pair of mustaches put there by mistake. ${ }^{33}$

Clochette's visage may be read as a résumé of fetishisms: situated in the netherworld of sexual identity, neither man nor woman, she literalizes the trope of dénégation or disavowal ("ni...ni"), which Freud saw as the general condition of the fetishist, affirming through his very denial of repression the presence of the repressed fetish. In textual terms, this denial corresponds to a kind of castrated narrative description. Cut, isolated and displaced, each tuft on Clochette's face becomes the object of intense visual focalization. As the text-face breaks into defamiliarized fragments, the reader imagines an act of mutilation on the female body. This sadistic coupure, typical of fetishistic pornography, is enlarged in the tragic conclusion of the story. Clochette was so nicknamed for her lame foot (cloche-pied), a result of a self-inflicted wound. As a young servant girl, she had thrown herself out of a window to save the reputation of a pusillanimous lover. The maimed foot, signifier of castrated femininity, is symbolically compensated for by the displaced mustache-a masculine signifier tacked onto a female face, as if to form a grotesque carnival mask (something like what Derrida, in Glas, has called "une plaie postiche"). ${ }^{34}$ The bearded lady thus becomes identifiable as a burlesque supplement, a prosthesis, fantasmatically guarding against separation and loss while at the same time derepressing an image of both the split ego and the text's rift.

A comparably "bisextual" servant figure, named, appropriately enough, "Barbe," appears in Georges Rodenbach's Bruges-la-morte (1892), the story of a widower whose despair is etched against the watery, grisaille backdrop of a Flemish city. This period piece, stylistically retro before its time, circles obsessively around the image of a dead woman's hair sealed in a bell jar (une cloche), and worshiped as a votive object:

- Pour la voir sans cesse, dans le grand salon toujours le même, cette chevelure qui était encore Elle, il l'avait posée là sur le paino désormais muet, simplement gisante-tresse interrompue, chaîne brisée, câble sauvé du naufrage! Et, pour l'abriter des contaminations, de l'air humide qui

33. Maupassant, Contes et nouvelles 2:851-52.

34. Jacques Derrida, Glas (Paris: Galilée, 1974), p. 250. 
l'aurait pu déteindre ou en oxyder le métal, il avait eu l'idée, naïve si elle n'eût pas été attendrissante, de la mettre sous verre, écrin transparent, boîte de cristal où reposait la tresse nue qu'il allait chaque jour honorer.

- In order to have this head of hair which was still Her continually in view in the large, unchanged salon, he had it placed on the piano, which would remain forever silent, faintly moaning-this interrupted tress, this broken chain, this cable saved from the shipwreck! And, so as to shelter it from any contamination, from the humid air that would have discolored or oxydized the metal, he had had the idea, seemingly naive if it had not been so endearing, of putting it under glass, a transparent casket, a crystal box in which the naked tress would sleep and to which he would pay homage every day. ${ }^{35}$

Like Clochette's face, blocked out in pieces, each site of hair geographically discrete, the tresses of the departed wife are similarly discomposed. Hugue's perception of her hair as an "interrupted" continuity - "une chaîne brisée" — connotes the revulsed or strabismic vision of the Freudian fetishist, who, unable to sustain contemplation of the maternal void, "interrupts" his gaze by refocusing on the nearest contiguous object. After falling for a dancer because of her golden mane (seemingly a replica of the dead woman's, later revealed to be a dyed postiche), Hugue is deserted by his pious servant. It is as if the hair of the deceased were taking its revenge through a barbe, itself displaced to a "cloche," which acts as a mediating trope between religious hats (mantes, coiffes, cloches) and bells. "Elle exultait," one learns of Barbe, "de s'acheminer vers son cher Béguinage, d'un pas encore alerte, dans sa grande mante noire à capuchon, oscillant comme une cloche [She exulted in going to her dear Beguinage, with a brisk footstep, in her huge black hooded cape, oscillating like a bell]" (BLM 57). Barbe "oscillates," a figure of undecidability, whose movement is gradually taken up by the incessant clanging of the bells:

- Cela lui faisait mal, ces cloches permanentes-glas d'obit, de requiem, de trentaines; sonneries de matines et de vêpres-tout le jour balançant leurs encensoirs noirs qu'on ne voyait pas et d'où se déroulait comme une fumée de sons.

- It got to him, those endless bells, obituary death knells, of the requiem, of the thirty-day mass; the ringing of matins and vespers-all day

35. Georges Rodenbach, Bruges-la-morte (Paris: Flammarion, 1987), p. 2o. Further ref erences will be abbreviated $B L M$. 
swinging their black censers, which one did not see and from which emanated what seemed to be a cloud of sounds. (BLM 75).

Psychologically destabilized by the persecuting death knell, Hugue murders his mistress, strangling her with the golden locks of his beloved. "La relique," states Pierre Fédida, commenting on this episode, "retient en elle une puissance de meurtre [The relic retains within itself the power of murder]."36 The story provides a macabre fictional analogue to the actual suicide of Maupassant's mother, Laure Le Poittevin, rumored to have strangled herself with her own hair.

Kofman's notion of fetishism lends itself to a rigorously hermeneutical approach to psychoanalysis because of its emphasis on the analytical structures of Freudian Verleugnung (disavowal) and Verneinung (negation)-that is, the fetishist's attempt to refute absence by fabricating an image that he knows to be false but which he believes in nonetheless. ${ }^{37}$ In searching for a more exclusively female fetishism, however, we are better served by the contemporary work of the feminist artist Mary Kelly. Kelly's Post-Partum Document, both a physical installation and a text, transforms the rites of childhood burial into the theory and aesthetic practice of female fetishism. ${ }^{38}$

36. Pierre Fédida, "La Relique et le travail du deuil," Nouvelle Revue de Psychanalyse, no. 2 (Autumn 1970): 250.

37. On this fetishistic logic of dénégation, see Octave Mannoni's "Je le sais bien, mais quand même...," in Clefs pour l'Imaginaire ou l'Autre Scène (Paris: Seuil, 1969), pp. 9-33.

38. Elizabeth Cowie has written an excellent analysis, "Introduction to PostPartum Document," $m / f$, no. 5-6 (1981): $115^{-23}$. In a section entitled "Motherhood, Loss, Fetish," she provides an interesting discussion of the visual absence of mother, father, and child: "the Post-Partum Document is not concerned with $a$ personal history but with the problem of the 'personal history' of motherhood. The deliberate absence of the human figure, of direct photographic images of Mary, the father Ray Barrie, or her son Kelly himself in the series is thus important. This strategy further underlines the work of the exhibition as representation rather than reflection and further distances it from autobiography. The fullness of identification with the image as realist representation, the human face, is refused. Instead we must make do, indeed work with the series of constructions of this personal history, to grasp it as constituted in a series of representations, markings, approximations, symbolisations and discourses. The personal experience of motherhood is the material for an exploration of motherhood in our society. That experience, of Mary Kelly's as a mother, is not however any self-evident truth, but appears as markings or traces, and in the gaps, losses and separations produced across the juxtaposition of the material of the exhibition. It is a process of representation by which the individual subject comes to be placed. Mary Kelly has suggested of Documentation IV, 
Questioning, like Derrida and Kofman, "the fetishistic nature of representation itself," Kelly takes deliberate steps toward shifting fetishism from its male-biased perspective. Within her theoretical mise-en-scène, the traditionally pictured upward gaze of boy to mother yields to the downward gaze of mother to child:

According to Freud, castration anxiety for the man is often expressed in fantasy as the loss of arms, legs, hair, teeth, eyes, or the penis itself. When he describes castration fears for the woman, this imaginary scenario takes the form of losing her loved objects, especially her children; the child is going to grow up, leave her, reject her, perhaps die. In order to delay, disavow, that separation she has already in a way acknowledged, the woman tends to fetishise the child: by dressing him up, by continuing to feed him no matter how old he gets, or simply by having another "little one." So perhaps in place of the more familiar notion of pornography, it is possible to talk about the mother's memorabiliathe way she saves things-first shoes, photographs, locks of hair or school reports. ${ }^{39}$

Basing her definition of maternal fetishism on Freud's discussion of feminine narcissism (the child qua maternal appendage becomes a means of restoring lost plenitude), Kelly hardly seeks to invalidate the proverbial equation of female fetishism with penis envy. Her aesthetic fabrication of a miniature museum of infantile detritus, however, privileges women in the role of (gender) constructors, preservationists, and caretakers. Post-Partum Document ironically frames a historic allegory of "motherhood," caught in a moment of ritual mourning for passing "babyhood." Kelly, it would seem, even goes

that 'to ref use to signify the mother through her image, photographic or otherwise, is not to erase her presence from the scene, but rather to locate her desire precisely in the field of the Other through the presence of the child.' 'Furthermore, because the figure of the mother is not present in the work, it does not suggest that the representation of femininity can escape the "corruption," the fetishistic implications, of conventional codes by evacuating the image. In the Post-Partum Document the realism which is repressed in the realm of the look returns in the form of the diary text.' The narrative capture, the story told, the titillating intimacy of confession are presented in these texts. But the 'story' actually only appears in the juxtaposition of these texts with the objects, becoming a statement of a process of positioning of mother and child in social relations. The objects and texts of the exhibition are important transitory, substitutive objects in this circulation. 'Her "memorabilia" and the child's "transitional objects" are emblems which testify to the threatened loss of mutual enjoyment, but the desire in which they are grounded can only be caused in the unconscious by the specific structure of phantasy'" (pp. 120-21).

39. Mary Kelly, Post-Partum Document (London: Routledge and Kegan Paul, 1985), p. xvi. 
so far as to endorse the manic tendencies of the Freudian melancholic whose collecting and conservation express a deep-seated need to appropriate and thereby incorporate the qualities of the elusive love object. Stripping away and ironically aestheticizing the negative associations surrounding the rituals of melancholia, Kelly transforms the maternal reliquary into a feminized poetics of mnemic traces, constitutive in turn of a (now positively valorized) genre of sentimentality. ${ }^{40}$

Comprehended in these terms, Maupassant's novel Une Vie (1883) offers itself to today's female reader as a fin-de-siècle pendant to Kelly's twentieth-century museological exhibitions. Une Vie chronicles the successive deceptions and depredations of a woman's life: starting with the discovery on her wedding night of the animal brutality of sex, and ending with the dreary solitude of widowhood and filial neglect. Jeanne contracts melancholia like some hereditary disease from her own mother, whose greatest masochistic pleasure is to sift through the wreckage of "billets doux" shored up in her "secrétaire aux têtes de sphinx" $(U V$ 155):

- Elle passait des jours à relire Corinne ou les Méditations de Lamartine; puis elle demandait qu'on lui apportât le tiroir "aux souvenirs". Alors ayant vidé sur ses genoux les vieilles lettres douces à son coeur, elle posait le tiroir sur une chaise à côté d'elle et remettait dedans, une à une, ses "reliques", après avoir lentement revu chacune. Et, quand elle était seule, bien seule, elle en baisait certaines comme on baise secrètement les cheveux des morts qu'on aima.

- She spent whole days re-reading Corinne or Lamartine's Meditations; or she would ask for her "relic drawer"; and having emptied out on her lap the old letters that were so precious to her, she put down the drawer on a chair by her side and replaced the "relics" one by one after slowly perusing each one. When she was alone, quite alone, she even kissed certain of them, as one kisses the lock of hair of someone whom one once loved and who is now dead. ( $U V{ }_{149}$; $\left.W L_{1} 123\right)$.

In response to her daughter's concern upon finding her mother in tears, the baroness replies: "Ce sont mes reliques qui m'ont fait ça.

4o. Kelly gives us a feminist transposition of what might be called the "discourse of the museum," a discourse grounded in literary representations of the collection (through techniques such as ekphrasis, the blason, enumeration, the héteroclite, the literary "passage" or "exposition universelle") by writers such as Balzac, Baudelaire, Flaubert, Zola, Henry James, Proust, Benjamin, and Adorno. 
On remue des choses qui ont été si bonnes et qui sont finies!... Tu connaîtras ça plus tard [It's my "relics" that do this to me. The memory of things that were so good once but are no more is stirred!... You'll experience the same thing later on yourself]" (UV 149; WL 123). With her "tu connaîtras ça plus tard," Jeanne's mother condemns her daughter to learning the coded language of morbid grief, with its hyperbolic, hyperfeminine rhetoric of nostalgia, self-pity, and loss. Though Jeanne dutifully learns to speak this language, she transposes it into a maternal dialect, commemorating her son's absence, for example, by turning his nickname-"Poulet" -into a verbal relic:

- Et, tout bas, ses lèvres murmuraient: "Poulet, mon petit Poulet", comme si elle lui eût parlé; et, sa rêverie s'arrêtant sur ce mot, elle essayait parfois pendant des heures d'écrire dans le vide, de son doigt tendu, les lettres qui le composaient. Elle les traçait lentement, devant le feu, s'imaginant les voir, puis, croyant s'être trompée, elle recommençait le $P$ d'un bras tremblant de fatigue, s'efforçant de dessiner le nom jusqu'au bout; puis, quand elle avait fini, elle recommençait.

- She kept whispering: "Pullet, darling little Pullet!" as if she were talking to him. His name sometimes put an end to her dreams, and she would spend hours trying to write the letters of his name in the air with an outstretched finger. She traced the letters slowly in front of the fire, imagining that she could see them; then, thinking that she had made a mistake, she began again with the P, her arm trembling with fatigue, forcing herself to complete the name; when she had finished it, she began all over again. ( $U V$ 219; WL 193-94)

Tracing the letter $P$ Jeanne substitutes the missing love object with a "mnemic trace" that is added in its turn to an already assembled collection of infant souvenirs. Most cherished of all objects is the "Poulet ladder"-knife-marks on a wood panel recording her child's development on the order of Mary Kelly's computation of fecal traces.

Jeanne's museological mania corresponds to what Stekel, in genderbiased terms, describes as the fetishist's "harem cult." "Every fetish adept," he wrote, "has his harem of handkerchiefs, drawers, shoes, braids, photographs, hair, corsets, garters, etc. Each single fetish loses its enchanting qualities as a fetish and the devotee quickly and hungrily finds himself another sample only to drag forth the old 
one again after a while; all just like a pasha in his harem." ${ }^{41} \mathrm{~A}$ female counterpart of Stekel's pasha, Jeanne collects frenetically, joyfully rediscovering and resurrecting the "little nothings" assembled by her in the past. Her gallery includes shattered cups, mother's lantern, father's broken cane, warming pans and water bottles, old calendars, her own gold hairpin, and Poulet's hallowed growth chart, which, like an epitaph, is festooned with loving inscriptions:

- Toutes les légères marques grimpaient sur la peinture à des intervalles inégaux; et des chiff res tracés au canif indiquaient les âges, les mois, et la croissance de son fils. Tantôt c'était l'écriture du baron, plus grande, tantôt la sienne, plus petite, tantôt celle de tante Lison, un peu tremblée. Et il lui sembla que l'enfant d'autrefois était là, devant elle, avec ses cheveux blonds, collant son petit front contre le mur pour qu'on mesurât sa taille.

Le baron criait: "Jeanne, il a grandi un centimètre depuis six semaines." Elle se mit à baiser le lambris, avec une frénésie d'amour.

- The lines on the paint went up at different intervals and the figures scratched with a penknife gave her son's age in years and months and his height. Sometimes it was in the Baron's large writing, sometimes in her smaller script, sometimes in Aunt Lison's rather shaky hand. She pictured him there in front of her, a fair-haired boy, as he was in those days, pressing his little forehead against the wall for them to measure his height. "Jeanne!" cried the Baron, "he's grown half an inch in the last six weeks," and she began to kiss the panel in a frenzy of affection. (UV 224; WL 199)

The saccharine tone of this passage, coupled with the reified, already quoted quality of the baron's phrase, recalls the lachrymose parsing of stock tombstone etiquettes or mourning mottos. Maupassant would later use this conceit-what one might call the lapidary verbal fetish-to greatest effect in his description of four engravings adorning a widow's parlor in Pierre et Jean (1888). With their maudlin captions, ironically signifying "widowhood," these pictures form a mise-en-abyme of the kitsch bourgeois culture of mourning. Funeral wreaths, miniatures in lockets, household shrines, mantelpiece urns, widow's crepe, mortuary figurines, letter packets, locks of hair, in short, the entire junkheap of personalized pompes funèbres,

41. Stekel, Sexual Aberrations, p. 21. 
when seen through Maupassant's satirical lens, emerges as a fetishistic iconography linked to feminine object cathexis.

The vaguely necrophilic aura surrounding these commemorative markers of loss has been derived by Maria Torok (glossing Ferenczi, Abraham, and Freud) from "the feeling of an irreparable sin: the sin of having been invaded by desire, of having been caught by an outpouring of libido at the least appropriate moment, the moment where it is befitting to abandon oneself to pain and despair." ${ }^{2}$ Though Torok herself never restricts this maladie du deuil (sickness of mourning) to the second sex, and though her signature paradigm of the return of the repressed-the phantasm of the exquisite cadaver-need in no way be identified as a feminine imago, her description of mourners who fixate on objects as representations both of loss and sepulchral desire fits easily into a model of female fetishism. ${ }^{43}$

Such a model, as we might now construe it, gives special weight to the woman's need for what Sandor Ferenczi called "objectal inclusion"; for "incorporation," "introjection," or encrypting, for anatomical self-reification (a kind of dismembered narcissism), and for sexual gratification through objects. ${ }^{44}$ In Une Vie, each of these

42. Maria Torok, "Maladie du deuil," p. 717.

43. Hair fetishism and necrophilia are linked in Maupassant's "La Chevelure" and "La Tombe," both published in 1884 . In the latter, told from a first-person male point of view, the hair is identified with the coprophilic allure of organic decay (Contes et nouvelles 2:216):

"She! It was she! I was seized with horror. But I put out my arm and caught her hair to pull this monstrous face towards me! It was at that moment I was arrested.

"All night I carried with me, as one retains the perfume of a woman after a sexual embrace, the filthy smell of this putrefaction, the odour of my beloved!" (The Collected Novels and Stories of Guy de Maupassant, trans. Ernest Boyd [New York: Knopf, 1923], p. 105).

If, in La Tombe, the fetish emerges as a singularly masculine necrophilic fantasm, typical, according to the Freudian construct, of the fetishist's urge to return to the infant utopia of anal eroticism and fecal "gifts," in Apparition, published a year earlier, death, hair, and female longing are configured. Here, in a haunted house, a feminine specter awaits release from this world when a man arrives to dispose of her eff ects. "Voulez-vous?... Voulez-vous?" she repeats, entreating him passionately to "rendre un grand service." Apparition is a tale of necrophilia in reverse: instead of a male protagonist satisfying his lust through intercourse with a dead woman, here we have a female corpse imposing sexual demands on the living (Contes et nouvelles 1:785): "'Comb my hair, oh! comb my hair; that will cure me; it must be combed. Look at my head-how I suffer; and my hair hurts me so!'... Why did I receive that comb with a shudder, and why did I take in my hands the long, black hair which gave to my skin a gruesome, cold sensation, as though I were handling snakes?" (The Collected Novels and Stories of Guy de Maupassant, p. 225).

44. Sandor Ferenczi, "Introjection and Transference," in First Contributions to 
dimensions is present in Jeanne's cloying habit of touching, fingering, and clinging to old things. "Elle apercevait mille bibelots connus jadis,... des riens qu'elle avait maniés,... Jeanne les touchait, les retournait, marquant ses doigts dans la poussière accumulée [She saw a thousand knickknacks, which she had known in former days...things which she had handled, trivial little things that had been lying around her.... Jeanne touched them and turned them round, dirtying her fingers in the accumulated dust)" (UV 201-2; $W L$ 176-77). Jeanne's gestures correspond to the notion of cramponnement, that "instinct of clinging," that "rhythm of little jerks," that oscillating sequence of strokes which Derrida situated "between crochet needles" ("entre crochets.") ${ }^{45}$

Derrida himself relates such cramponnements to fetishism, discerning in les maniements, or manic clinginess, a desire to fix, immobilize, and reify a truth-value that is constantly slipping away toward its parodic double, or postiche representation. But if we accept this argument, it means that we are willing to grant Derrida (and Kofman) their gender generalized fetishism of oscillation and undecidability. If one prefers a theory accenting a distinctly female fetishism, the notion of cramponnement might alternatively be affixed to the feminine expression of postpartum sentimentality. This particular mode of sentimentality, applied to an indifferent lover rather than a lost child, is discernible in Maupassant's magnum opus Bel-Ami (1885), where the aging wife of a newspaper magnate, about to be abandoned by the ruthless, arriviste Du Roy, manages to ensnare him, to encrypt him, so to speak, with a ring of hair:

- Elle frottait lentement sa joue sur la poitrine du jeune homme, d'un mouvement câlin et régulier, et un de ses longs cheveux noirs se prit dans le gilet.

Elle s'en aperçut, et une idée folle lui traversa l'esprit, une de ses idées superstitieuses qui sont souvent toute la raison des femmes. Elle se mit à enrouler tout doucement ce cheveu autour du bouton. Puis elle en

\footnotetext{
Psycho-Analysis (London: Hogarth Press, 1952), pp. 40-43. J. Laplanche and J. B. Pontalis have defined incorporation, introjection, and their close relationship as follows: "Incorporation contains three meanings: it means to obtain pleasure by making an object penetrate oneself; it means to destroy this object; and it means, by keeping it within oneself, to appropriate the object's qualities....Introjection is close in meaning to incorporation, which indeed provides it with its bodily model, but it does not necessarily imply any reference to the body's real boundaries (introjection into the ego, into the ego-ideal, etc.)" (The Language of Psychoanalysis, trans. Donald Nicholson-Smith [New York: Norton, 1973], pp. 212, 229).

45. Jacques Derrida, "Entre crochets," Digraphe, no. 8 (1976): 97-114.
} 
attacha un autre au bouton suivant, un autre encore à celui du dessus. $\mathrm{A}$ chaque bouton elle en nouait un.

- She was slowly rubbing her head to and fro against the young man's chest, gently stroking him, and one of her long black hairs caught in his waistcoat.

She noticed it and a wild notion suddenly came into her head, one of those superstitious ideas which are of ten a woman's only form of reason. Very gently she started to wind the hair around the button. Then she fastened another one to the next button and another one to the button above. To each of his buttons she attached one hair. ${ }^{46}$

Rubbing against him with short, regular movements Madame Walter mimes the work of knitting needles. This masturbatory gesture, entre crochets, announces a fantasy as perverse as that of any male fetishist - a fantasy confusing the real and the simulacrum, a hypersentimentalized clinging to a surrogate sex or prosthesis. But is this substitute sex simply a figure of her own sex?

- Il emporterait quelque chose d'elle sans le savoir, il emporterait une petite mèche de sa chevelure, dont il n'avait jamais demandé. C'était un lien par lequel elle l'attachait, un lien secret, invisible! un talisman qu'elle laissait sur lui.

- And without knowing it he would take away something of hers, a little lock of hair, a thing for which he had never asked. It was a link by which she would be binding him to her, a secret, invisible link, a talisman that she was leaving with him. ( $B A 283 ; B$ 326-27).

Though Madame Walter abases herself before her lover there is nonetheless a kind of narcissism and self-aggrandizement in this circular figuration of hair. The ring connotes a noose leading back to its owner, or, at the very least, to an image of woman enclosed on herself, involved, like the classic male fetishist, in a self-referential erotic fantasy.

Indeed, it is this narcissistically ordered female fetishism that acquires specular form in Bel-Ami. As Du Roy moves from one mistress to the other, he is caught out by the hair, which claims him like a sticky trace of the dead. While undressing him, Clotilde

46. Guy de Maupassant, Bel-Ami (Paris: Garnier-Flammarion, 1959), p. 283; trans. Douglas Parmée as Bel-ami (Harmondsworth: Penguin, 1975), p. 326. Further ref erences to the French edition will be abbreviated $B A$; those to the English, simply $B$. 
discovers the strand, fingering and inspecting it like a detective. After unwinding the third knot, she pales, exclaiming: "Oh! tu as couché avec une femme qui t'a mis des cheveux à tous tes boutons [Oh, you've been to bed with a woman who's put hairs on all your buttons]" ( $B A$ 286; $B$ 330). Clotilde recognizes the fetishism of the other woman where Du Roy fails to do so. "Elle avait deviné, avec son instinct rusé de femme, et elle balbutiait, furieuse, rageant et prête à pleurer:-Elle t'aime, celle-là...et elle a voulu te faire emporter quelque chose d'elle [Her woman's crafty instinct told her what had happened and, furious with anger, on the point of tears, she stammered: 'She's a woman who loves you... and she wanted you to take something of hers away with you ]" $(B A 286 ; B 330-31)$. "Vouloir faire emporter quelque chose d'elle"-this repeated construction epitomizes a kind of gynotextual fetishism in the second degree. In the figure of two women meeting invisibly over the buttons of their common lover we have a sudden revelation of the female fetishist no longer "split" by the gaze of a male Other but, rather, absorbed and reified in an identical and mutually identified look. This circular gaze is reinforced by the recurrent image of a ring of hair: "Garde ta vieille femme ... garde-là," rails the outraged Clothilde, "fais-toi faire une bague avec ses cheveux... avec ses cheveux blancs.... Tu en as assez pour ça [You can stick to your old woman ... stick to her... have a ring made with her hairs ... her white hairs.... You've got enough of them to do that]" (BA 287; $B$ 331 ).

With its emphasis on a frozen moment of peripeteia (unmasking the complicity of two women in the making and unraveling of a lover's discourse), this scene highlights the specular nature of feminine longing. Anticipating Luce Irigaray's Speculum of the Other Woman, Maupassant's characters suffer a violation of trust at the hands of men, but at the same time discover in their pantomime of each other a "language of their own."

Using this language of a gynotextual desire that recognizes the feminine relic as symbolizing something both more than and less than a simple compensatory object, we might better understand the polysemic character of female fetishism. Whether standing in for lover, parent, child, or female double, the female fetish belongs to an erotic economy of severance and disappropriation, itself less fixed on a fiction of castration anxiety. In interpreting Freud's statement that the "horror of castration sets up a sort of permanent memorial to itself by creating this (fetish) substitute," I am tempted 
to retain his concept of a memorial or marker to which the female subject "clings" but would want to question the preeminence of a "castrated" site within the female fetishist's Imaginary. ${ }^{47}$

Having attempted to challenge the obsession with emasculation so frequently evinced in male-biased psychoanalysis, and having tried, concordantly, to establish epistemological categories for thinking female loss as something other than just penis envy or a masqueraded castration anxiety, I have come increasingly to value Mary Kelly's pioneering “work of mourning." In her Post-Partum Document, the accent on woman's "genital deficiency" is displaced by a poetics of loss, fluids, and ghostly stains, which themselves paradoxically acquire conceptual bulk. For Kelly, the transgressively eroticized mourning of missing love objects becomes substantial in its own right, weaned from supraphallic explanation.

And these repetitively phallic explanations certainly continue to prevail. As recently as 1981 , for example, the French psychoanalyst Gérard Bonnet offered an account of his own patient's history of female fetishism, which, though enlightened in regard to the need to redress the lack of material on female perversion, nonetheless reaches conclusions not so dissimilar from those of Clérambault. Bonnet begins by recognizing the extent to which the salient points of his subject's case-the substitution and surinvestment of an inanimate object, the necessity of the object to the production of jouissance, the elaboration of a "perverse" mise-en-scène-match the requisite coordinates of male fetishism. "Lucie" experiences orgasm, much like Clérambault's female silk fetishists, only when the relics of an ancient bathrobe are placed between her thighs. Ingeniously, Bonnet traces the choice of fetish object to a vestigial text-Octave Mirbeau's Le Journal d'une femme de chambre - introduced to the patient by her mother, who had bragged that she herself had performed services for a foot fetishist much like the maid in this turn-of-the-century novel. Correlating the words robe de chambre with femme de chambre, in the context of Lucie's absent father, Bonnet at first sees her "possession" of the dressing gown as a symbolic formulation of "having" the paternal phallus. But having provided the grounds for decentering the Freudian emphasis on the male fetishist's problematic of "having and not-having" the maternal phallus, Bonnet reverts to a more orthodox line of interpretation. Pointing out to Lucie that the consonants in RoBe de

47. Freud, "Fetishism," p. 200. 
CHamBRe yield BoRD de BRanCHe, or "wood plank," he concludes that her bathrobe fetish discloses a phantasm of wishing to "be" that maternal supplement or strut ("une planche de salut") that is traditionally projected by the male fetishist. In a manner disquietingly close to that of Clérambault, Bonnet rephallicizes the female fetishist's inner arena of the symbolic, arguing that she is "fétichée" (fetishized for and by her mother) rather than "fétichiste." 48 Though Bonnet, like Kofman, opts for the "undecidability" hypothesis in relation to female fetishism, arguing that Lucie's symptoms signify a perpetual oscillation between maternal and paternal phallus, his case study ends in equivocation. Lucie is "not not" a fetishist. Though her robe functions like a "transitional object" (and here Bonnet, like so many analysts, implicitly infantilizes women "perverts" by placing them regressively in the realm of the Kleinian preoedipal), it also shares the pure instrumentality of the sexual fetish object. Female fetishism, like female perversion in general, is thus estimated by Bonnet to be "furtive" and "hardly formulated [à peine formulée]." 49 The point could hardly be made more clearly: from Clérambault to Gérard Bonnet, the standard psychoanalytical account of female fetishism has remained woefully impoverished from a theoretical perspective.

In concluding this discussion, I am aware of the problem, inherent in my own approach, of seeming to validate a negative stereotype of female sexuality. But the purpose of this investigation has been neither to promote female fetishism (though I do think women have a right to be perverse!), nor to intimate that women are necessarily locked into rigid codes of hypersentimentality. My concern, rather, has been to experiment with recuperating what the cultural anthropologist Clifford Geertz has called "thick descriptions" of women's behavior, locating in the representation of feminine collecting (from Maupassant and Clérambault to Kelly) documents on which to draw in the task of revising sclerotic psychoanalytic configurations of female eroticism.

48. Gérard Bonnet, "Fétichisme et exhibitionnisme chez un sujet féminin," in Voir, être vu: Etudes cliniques sur l'exhibitionnisme, 2 vols. (Paris: PUF, 1981), 1:93-94. 49. Gérard Bonnet, Les Perversions sexuelles (Paris: PUF, 1983), p. 117. 